\title{
PENYUSUNAN PAKET PELATIHAN PENGEMBANGAN KECERDASAN INTRAPERSONAL UNTUK MAHASISWA
}

\author{
Rina Sukawati
}

\begin{abstract}
The purpose of this research was to develop training package for intrapersonal intelligence development for the students of Educational Technology Department, School of Education, State University of Jakarta. The package was develop by employing Instructional Development Model. The research resulted in training package for intrapersonal intelligence development for the university students which is expected to be applicable or adjustable for trainings and the other universities for the similar purposes. A set of recommendation is given in using this package to be effective and efficient.
\end{abstract}

Keywords: instructional development model, training package, intrapersonal intelligence.

\section{PENDAHULUAN}

\section{Latar Belakang Masalah}

Universitas Negeri Jakarta (UNJ) mengemban fungsi untuk mengembangkan potensi Sumber Daya Manusia (SDM) di bidang pendidikan dan nonkependidikan yang mandiri dan memiliki integritas sesuai dengan tuntutan pembangunan yang berkesinambungan. Kompetensi lulusan UNJ dalam bidang akademik, profesi atau vokasi meliputi sebagai berikut.

1. Kemampuan untuk menguasai, menerapkan, dan mengembangkan ilmu, teknologi, dan seni untuk mencapai keunggulan di bidang kependidikan maupun nonkependidikan sesuai dengan tuntutan pada tingkat nasional, regional, maupun internasional.

2. Kemampuan untuk mandiri dan memiliki budaya kewirausahaan, memiliki kemampuan profesional dan integritas yang tinggi, yang memungkinkan mereka mampu bersinergi dan berkompetisi secara sehat dalam era informasi dan pasar bebas pada tingkat nasional, regional, maupun internasional.

3. Kemampuan profesional yang tinggi untuk menerapkan dan mengembangkan ilmu, teknologi,dan seni sesuai dengan tuntutan pembangunan nasional yang berkesinambungan.

4. Kemampuan untuk meningkatkan kualitas diri, wawasan, dan sikap dalam upaya proses internalisasi nilai/kaidah ilmiah dalam menunaikan tugas-tugas keprofesionalannya.

5. Kemampuan menciptakan, menemukan, mengembangkan berbagai ilmu, dan teknologi baik di bidang kependidikan dan nonkependidikan yang sesuai dengan keprofesionalannya.
Kompetensi lulusan UNJ di atas menjadikan kecerdasan intrapersonal sebagai prioritas utama. Hal ini tersirat di dalam kompetensi 2, 3, dan 4. Setiap kompetensi tersebut mengacu pada sikap-sikap profesionalisme, kemandirian, integritas, dan pengembangan aktualisasi potensi diri mahasiswa UNJ.

Mahasiswa UNJ memiliki usia yang beragam berkisar antara 18-21 tahun, secara psikologis merupakan tahap peralihan remaja akhir menuju dewasa dini. Berdasarkan data empirik yang peneliti dapatkan mengenai rata-rata Indeks Prestasi Kumulatif (IPK) semester ganjil (083) UNJ tahun angkatan 2005-2006 seperti tertera pada tabel 1.

Tabel 1. Indeks Prestasi Mahasiswa Per Semester

\begin{tabular}{|l|c|c|c|c|c|}
\hline \multicolumn{5}{|c|}{ Indeks Kumulatif Mahasiswa Per Semester (083 ) } \\
\hline \multirow{2}{*}{ Trogram Studi } & Jmlh & IP & Rata2 & \multirow{2}{*}{ MIN } & MAKS \\
\cline { 2 - 5 } & Mhs & $<2,00$ & IP & & \\
\hline Psikologi Pendidikan & 102 & 1 & 2,77 & 1,83 & 3,8 \\
\hline Teknologi Pendidikan & 294 & 2 & 2,81 & 1,5 & 4 \\
\hline Pend. Luar Biasa & 233 & 0 & 2,8 & 2,14 & 3,77 \\
\hline Manajemen Pendidikan & 330 & 0 & 2,88 & 2,34 & 4 \\
\hline Pendidikan Luar Sekolah & 227 & 3 & 2,61 & 1,21 & 3,65 \\
\hline PAUD & 390 & 0 & 2,72 & 2,22 & 3,73 \\
\hline PGTK & 237 & 0 & 2,88 & 2,48 & 4 \\
\hline PGSD & 868 & 6 & 2,67 & 1,61 & 4 \\
\hline Bimbingan Konseling & 283 & 0 & 2,76 & 2,38 & 3,87 \\
\hline Pend. Bhs \& Sast, Indo & 271 & 1 & 2,78 & 1 & 4 \\
\hline Bhs \& Sast. Indonesia & 165 & 0 & 2,76 & 2,37 & 4 \\
\hline Pend. Bahasa Inggris & 375 & 8 & 2,4 & 1,47 & 4 \\
\hline Bhs \& Sastra Inggris & 217 & 7 & 2,3 & 1,52 & 3,84 \\
\hline Pend. Bahasa Perancis & 238 & 3 & 2,27 & 1,82 & 3,8 \\
\hline Pend. Seni Rupa & 247 & 5 & 2,17 & 1,78 & 3,7 \\
\hline Pendidikan Seni Tari & 136 & 1 & 2,3 & 1,4 & 3,6 \\
\hline Pend. Bahasa Jerman & 159 & 3 & 2,37 & 1 & 3,88 \\
\hline Pend. Bahasa Arab & 247 & 3 & 2,56 & 1,81 & 4 \\
\hline Bahasa Arab & 13 & 0 & 2,61 & 2,09 & 3,57 \\
\hline
\end{tabular}




\begin{tabular}{|l|c|c|c|c|c|} 
Pend. Seni Musik & 230 & 4 & 2,38 & 1,57 & 3,90 \\
\hline Pend. Matematika & 346 & 15 & 2,35 & 1,55 & 4,00 \\
\hline Matematika & 157 & 5 & 2,23 & 1,90 & 4,00 \\
\hline Pendidikan Fisika & 239 & 0 & 2,39 & 2,17 & 3,80 \\
\hline Fisika & 113 & 12 & 2,01 & 1,15 & 3,80 \\
\hline Pendidikan Kimia & 230 & 1 & 2,38 & 2,00 & 3,68 \\
\hline Kimia & 127 & 3 & 2,20 & 1,44 & 3,56 \\
\hline Pendidikan Biologi & 235 & 0 & 2,38 & 2,10 & 3,75 \\
\hline Biologi & 138 & 2 & 2,26 & 1,90 & 3,61 \\
\hline PP \& Kewarganegaraan & 253 & 2 & 2,62 & 1,55 & 3,87 \\
\hline Public Relation & 153 & 2 & 2,46 & 1,00 & 3,84 \\
\hline Pendidikan Geografi & 209 & 0 & 2,64 & 2,20 & 4,00 \\
\hline Pendidikan Sejarah & 377 & 1 & 2,78 & 1,57 & 3,80 \\
\hline Pariwisata & 72 & 1 & 2,50 & 1,92 & 3,68 \\
\hline IPI & 112 & 1 & 2,50 & 2,00 & 3,95 \\
\hline IKPI & 23 & 1 & 2,56 & 1,86 & 3,73 \\
\hline Pendidikan Sosiologi & 125 & 0 & 2,75 & 2,27 & 4,00 \\
\hline Sosiologi Pemb. & 138 & 5 & 2,37 & 1,73 & 3,76 \\
\hline Pend. Teknik Elektro & 214 & 7 & 2,41 & 2,00 & 3,63 \\
\hline Pend. Teknik Elektronika & 193 & 4 & 2,40 & 2,00 & 3,63 \\
\hline Teknik Elektronika & 139 & 4 & 2,26 & 2,00 & 3,40 \\
\hline Pend. Teknik Mesin & 374 & 7 & 2,13 & 1,59 & 3,54 \\
\hline Pend. Tek. Otomotif & 8 & 0 & 2,25 & 2,53 & 3,01 \\
\hline Teknik Mesin & 247 & 2 & 2,22 & 2,00 & 3,45 \\
\hline & & & & & \\
\hline
\end{tabular}

Setelah mengamati data tersebut dapat disimpulkan bahwa dari 67 program studi yang ada di UNJ, 53 program studi masih memiliki mahasiswa yang nilai IPK-nya kurang dari 2, sedangkan hanya 14 program studi di UNJ yang nilai IPK mahasiwanya tidak kurang dari 2. Standar nilai minimal IPK 2

\begin{tabular}{|l|c|c|c|c|c|} 
Pend. Teknik Bangunan & 176 & 1 & 2,24 & 2,00 & 3,39 \\
\hline Teknik Sipil & 89 & 6 & 2,14 & 1,85 & 3,70 \\
\hline Trans. Laut \& Kepela & 247 & 9 & 2,23 & 1,57 & 3,73 \\
\hline I. Kesejaht. Keluarga & 34 & 0 & 2,50 & 2,41 & 3,48 \\
\hline Pendidikan Tata Boga & 220 & 1 & 2,68 & 1,70 & 3,77 \\
\hline Pend. Tata Busana & 236 & 1 & 2,63 & 2,00 & 3,70 \\
\hline Pendidikan Tata Rias & 135 & 0 & 2,80 & 2,51 & 4,00 \\
\hline Tata Boga & 79 & 1 & 2,54 & 2,00 & 3,67 \\
\hline Tata Busana & 73 & 0 & 2,80 & 2,31 & 3,79 \\
\hline Tata Rias & 37 & 2 & 2,75 & 1,87 & 3,59 \\
\hline Pendidikan Jasmani & 514 & 18 & 2,23 & 0,33 & 3,60 \\
\hline Olahraga Rekreasi & 108 & 3 & 2,29 & 1,00 & 3,51 \\
\hline Pend. Kepelatihan & 415 & 12 & 2,25 & 0,37 & 3,59 \\
\hline Pend, Kepelatihan & 77 & 13 & 2,12 & 1,00 & 3,77 \\
\hline llmu Keolahragaan & 189 & 4 & 2,45 & 0,40 & 3,80 \\
\hline Pend. Adm Perkantoran & 368 & 12 & 2,58 & 0,49 & 3,90 \\
\hline Pend. Eko \& Koperasi & 229 & 4 & 2,56 & 0,30 & 3,73 \\
\hline Pend. Tata Niaga & 262 & 4 & 2,52 & 1,22 & 3,70 \\
\hline Sekretaris & 81 & 1 & 2,23 & 2,00 & 3,57 \\
\hline Manajemen & 66 & 15 & 2,01 & 1,30 & 4,00 \\
\hline Pemasaran & 128 & 13 & 2,20 & 0,45 & 3,75 \\
\hline Pendidikan Akuntansi & 378 & 0 & 2,74 & 2,18 & 3,90 \\
\hline Akuntansi & 211 & 2 & 2,52 & 1,67 & 3,83 \\
\hline Akuntansi & 40 & 2 & 2,45 & 1,68 & 3,89 \\
\hline
\end{tabular}

berdasarkan pada ketetapan nilai IPK dan standar kelulusan (nilai yudisium) di UNJ.

Berdasarkan data empirik yang peneliti dapatkan terhadap program studi di UNJ mengenai prosentase lama studi mahasiswa Program Studi Teknologi Pendidikan FIP-UNJ, tertera dalam tabel 2.

Tabel 2. Program Studi: S1 Teknologi Pendidikan.

\begin{tabular}{|c|c|c|c|c|c|c|c|c|}
\hline \multicolumn{9}{|c|}{ Program Studi: S1 Teknologi Pendidikan } \\
\hline \multirow{3}{*}{$\begin{array}{l}\text { Tahun } \\
\text { Lulus }\end{array}$} & \multicolumn{6}{|c|}{ Lama Studi } & \multirow{3}{*}{$\begin{array}{l}\text { Total } \\
\text { Lulusan }\end{array}$} & \multirow{3}{*}{$\begin{array}{c}\text { Lama Studi } \\
\text { Rata-rata }\end{array}$} \\
\hline & \multicolumn{2}{|c|}{$4,0-4,5$} & \multicolumn{2}{|c|}{$>4,5-5,0$} & \multicolumn{2}{|c|}{$>5,0$} & & \\
\hline & $\overline{J L H}$ & $\%$ & JLH & $\%$ & $\overline{\mathrm{JLH}}$ & $\%$ & & \\
\hline $2001 / 2002$ & 11 & 34 & 7 & 21 & 14 & 43 & 32 & 5,18 \\
\hline $2002 / 2003$ & 28 & 59 & 11 & 23 & 8 & 17 & 47 & 4,67 \\
\hline $2003 / 2004$ & 12 & 41 & 4 & 13 & 13 & 44 & 29 & 5,2 \\
\hline $2004 / 2005$ & 12 & 28 & 15 & 35 & 15 & 35 & 42 & 5,07 \\
\hline $2005 / 2006$ & 19 & 47 & 6 & 15 & 15 & 37 & 40 & 5,01 \\
\hline TOTAL & 82 & & 43 & & 65 & & 190 & \\
\hline
\end{tabular}

Berdasarkan data tersebut dapat disimpulkan bahwa persentase lama studi selama 4,0-4,5 tahun (lulus tepat waktu) dalam kurun waktu lima tahun terhitung pada tahun 2001-2006 pada program studi S1 Teknologi Pendidikan adalah rata-rata $41,8 \%$; kurang dari 50\% jumlah keseluruhan mahasiswa S1 Teknologi Pendidikan. Selain data di atas, peneliti tidak mendapatkan data mahasiswa yang dikeluarkan (drop out) karena tidak memenuhi standar nilai IPK yang ditetapkan.
Setelah menganalisis kedua tabel di atas dapat disimpulkan bahwa adanya kesenjangan antara standar ideal yang ditetapkan oleh UNJ dengan kenyataan yang ada di lapangan sehingga menimbulkan masalah yang harus segera dipecahkan. Hal ini akan mengakibatkan penurunan kualitas SDM profesional dan bermutu tinggi yang dihasilkan oleh UNJ. Permasalahan di atas disebabkan oleh beberapa faktor diantaranya rendahnya motivasi belajar mahasiswa, kurangnya kemandirian dalam belajar, 
serta kurangnya pengetahuan tentang cara belajar yang efektif dan efisien. Dari hasil pengamatan peneliti, ketiga faktor tersebut disebabkan oleh rendahnya kemampuan mahasiswa dalam memahami potensi dirinya sendiri.

Pada awal masa studi, mahasiswa Program Studi Teknologi Pendidikan FIP-UNJ mengalami proses adaptasi dalam masa perkuliahan. Pada proses adaptasi mahasiswa menghadapi banyak hambatan dan tantangan dalam tahun pertama perkuliahan berlangsung. Di sini terlihat adanya gejala bahwa mahasiswa tingkat dua mengalami krisis identitas dan kemandekan aktualisasi potensi diri sehingga berakibat menurunnya motivasi dalam proses pembelajaran di perkuliahan.

Berdasarkan pernyataan di atas dapat disimpulkan bahwa kemampuan seseorang dalam memahami potensi dirinya merupakan bagian dari kecerdasan intrapersonal (intrapersonal intelligences). Kecerdasan intrapersonal memiliki peranan yang sangat penting dalam proses perkembangan masa remaja akhir menuju dewasa dini. Kecerdasan intrapersonal sangat berpengaruh terhadap kualitas SDM di perguruan tinggi/universitas. Oleh karena itu, pengembangan kecerdasan intrapersonal sangat diperlukan oleh mahasiswa di perguruan tinggi/ universitas agar mereka dapat menjadi SDM yang bermutu tinggi.

Tantangan-tantangan yang telah dipaparkan di atas disadari sebagai masalah belajar. Ilmu yang mendalami tentang masalah belajar dan pemecahannya adalah Teknologi Pendidikan. Fokus Teknologi Pendidikan adalah pada proses bagaimana teknologi perangkat lunak dan keras digunakan untuk mengkomunikasikan pengetahuan, keterampilan, atau sikap kepada pemelajar (si belajar) agar mengalami perubahan perilaku seperti yang diharapkan (Suparman, 2001:25). Untuk menghasilkan lulusan Teknologi Pendidikan yang profesional, tangguh, dan bermutu tinggi maka diperlukan pendidikan yang bermutu tinggi pula.

Pembahasan yang akan disampaikan pada tulisan ini berfokus pada penerapan Model Pengembangan Instruksional (MPI) di dalam menyusun paket pelatihan kecerdasan intrapersonal untuk mahasiswa reguler Program Studi Teknologi Pendidikan FIP-UNJ angkatan 2004. Model yang akan dijadikan sebagai acuan adalah model MPI; yang akan digunakan di dalam menyusun paket pelatihan kecerdasan intrapersonal. Pada dasarnya, setiap orang sudah memiliki kecerdasan tersebut sejak lahir, tetapi masih banyak orang yang belum mengembangkannya secara optimal. Pelatihan menjadi salah satu solusi dalam menyelesaikan masalah ini karena pelatihan merupakan proses pembelajaran yang dilakukan dalam waktu relatif singkat.

\section{Rumusan Masalah}

Rumusan masalah dalam tulisan ini adalah Apakah Paket Pelatihan Pengembangan Kecerdasan Intrapersonal yang menerapkan model MPI dapat mengatasi krisis identitas dan kemandekan aktualisasi potensi diri mahasiswa perguruan tinggi/universitas?

\section{KAJIAN TEORETIS}

Penerapan MPI di dalam menyusun paket pelatihan kecerdasan intrapersonal berorientasi produk ini menghasilkan satu paket pelatihan yang ditujukan untuk mahasiswa Program Studi Teknologi Pendidikan FIP-UNJ reguler angkatan 2004. Penerapan MPI di dalam menyusun paket pelatihan kecerdasan intrapersonal, diharapkan mampu mengatasi permasalahan mengenai krisis identitas dan kemandekan aktualisasi potensi diri mahasiswa Program Studi Teknologi Pendidikan FIP-UNJ angkatan 2004. MPI dalam paket pelatihan kecerdasan intrapersonal ini disusun secara praktis dan mengacu pada aktualisasi potensi diri baik secara intelektual maupun emosional. Penerapan MPI di dalam menyusun paket pelatihan kecerdasan intrapersonal ini berisi langkah-langkah praktis bagi mahasiswa yang ingin (1) mengenal dirinya, (2) memahami kekuatan dan kelemahannya, (3) meningkatkan motivasi belajar, (4) mengendalikan emosi/perasaan dengan benar, (5) mampu merumuskan tujuan hidup, dan (6) membuat perencanaan tujuan hidupnya dengan benar, serta (7) menerapkan strategi belajar secara efektif dan efisien.

Melalui penerapan model MPI di dalam menyusun paket pelatihan kecerdasan intrapersonal, dihasilkan mahasiswa calon pendidik yang mampu menghadapi tantangan hidup di masa mendatang. Dengan demikian, mereka akan berkembang menjadi manusia yang mandiri, tangguh, profesional, dan bermutu tinggi. Penerapan MPI di dalam menyusun paket pelatihan kecerdasan intrapersonal ini menggunakan prinsip-prinsip belajar dan pembelajaran. Penerapan model MPI tersusun secara sistematis dan sistemik mulai dari (1) proses analisis, (2) desain, (3) pengembangan, (4) implementasi, dan (5) evaluasi untuk mengembangkan keahlian dan kemampuan mahasiswa di perguruan tinggi/ universitas secara praktis terhadap pengetahuan serta keterampilan melalui pelatihan kecerdasan Intrapersonal. Hasil penerapan model (MPI) di dalam 
menyusun paket pelatihan kecerdasan intrapersonal adalah sumber belajar yang telah siap pakai berupa satuan pembelajaran (paket pelatihan).

Uji coba Paket Pelatihan Pengembangan Kecerdasan Intrapersonal ini dilakukan di Program Studi Teknologi Pendidikan FIP-UNJ. Model pengembangan pembelajaran yang digunakan oleh peneliti sebagai acuan dalam pengembangan pelatihan kecerdasan intrapersonal adalah MPI. Prosedur atau langkah-langkah dalam MPI dijadikan acuan dalam mengembangkan Paket Pelatihan Pengembangan Kecerdasan Intrapersonal untuk mahasiswa Teknologi Pendidikan FIP-UNJ reguler angkatan 2004. Artinya, dalam mengembangkan Paket Pelatihan Pengembangan Kecerdasan Intrapersonal untuk mahasiswa Program Studi Teknologi Pendidikan FIP-UNJ reguler angkatan 2004, seluruh langkah dalam MPI dilaksanakan secara tuntas.

Pemilihan model MPI selain langkahnya yang praktis, model ini memiliki komponen yang lengkap dan cukup sesuai untuk mengembangkan pelatihan di Teknologi Pendidikan FIP-UNJ. Prosedur dalam model MPI melalui proses yang sistematis untuk membangun sistem instruksional yang efektif dan efisien. Selain itu, model MPI juga praktis dan fleksibel untuk digunakan oleh praktisi pendidikan baik junior maupun senior yang dapat disesuaikan dengan kondisi pembelajar, mahasiswa, dan lingkungan, serta sumber-sumber lain yang tersedia. Hal yang terpenting adalah model MPI sesuai dengan kebutuhan peneliti sebagai pengembang pembelajaran serta relevan digunakan di dalam pengembangan di tingkat perguruan tinggi, khususnya di Program Studi Teknologi Pendidikan FIP-UNJ.

Dalam penerapan model MPI di dalam menyusun paket pelatihan kecerdasan intrapersonal ini, komponen atau tahapan dalam model MPI disesuaikan dengan pendekatan pembelajaran di Program Studi Teknologi Pendidikan FIP-UNJ. Menurut Suparman (2001), penerapan model MPI di dalam menyusun paket pelatihan kecerdasan intrapersonal dilaksanakan berdasarkan kesembilan langkah model MPI, yaitu: (1) mengidentifikasi kebutuhan pembelajaran dan merumuskan Tujuan Pembelajaran Umum (TPU), (2) melakukan analisis pembelajaran, (3) mengidentifikasi perilaku dan karakteristik awal mahasiswa, (4) merumuskan Tujuan Pembelajaran Khusus (TPK), (5) menulis tes acuan patokan, (6) menyusun strategi pembelajaran, (7) mengembangkan bahan pembelajaran, (8) mendesain dan melaksanakan evaluasi formatif, dan (9) mendapatkan sistem pembelajaran.
Pada langkah pertama, mengidentifikasi kebutuhan pembelajaran dan menulis TPU mengacu pada analisis kebutuhan pembelajaran yang terdapat di dalam rumusan masalah tulisan ini. Prosedur mengidentifikasi kebutuhan pembelajaran pada MPI berhenti setelah diperoleh perilaku umum yang perlu diajarkan kepada mahasiswa.

Langkah kedua, melakukan analisis pembelajaran berdasarkan pada teori hakikat pelatihan kecerdasan intrapersonal. Kegiatan ini adalah menjabarkan perilaku umum menjadi perilaku yang lebih kecil atau spesifik serta mengidentifikasi hubungan antara perilaku spesifik yang satu dengan perilaku spesifik yang lain. Proses menganalisis pembelajaran yang digunakan oleh MPI didasarkan kepada berpikir logis, analitis, dan sistematis.

Langkah ketiga, mengidentifikasi perilaku dan karakteristik awal mahasiswa mengacu pada teori hakikat mahasiswa Program Studi Teknologi Pendidikan FIP-UNJ, karakteristik mahasiswa Teknologi Pendidikan FIP-UNJ reguler angkatan 2004, tugas-tugas perkembangan masa remaja akhir, dan kompetensi lulusan mahasiswa Program Studi Teknologi Pendidikan FIP-UNJ. Kegiatan ini merupakan proses untuk mengetahui perilaku (kompetensi) yang dikuasai mahasiswa sebelum mengikuti pelatihan, bukan untuk menentukan perilaku prasyarat dalam rangka menyeleksi mahasiswa sebelum mengikuti pelatihan. Kegiatan ini menganut pendekatan menerima mahasiswa apa adanya dan menyusun sistem pembelajaran (pelatihan) atas dasar keadaan mahasiswa tersebut.

Hasil akhir dari kegiatan mengidentifikasi perilaku dan karakteristik mahasiswa adalah menentukan garis batas antara perilaku yang tidak perlu diajarkan dan perilaku yang harus diajarkan kepada mahasiswa. Perilaku yang diajarkan ini kemudian dirumuskan dalam bentuk TPK. Selanjutnya, langkah keempat adalah menulis TPK. Perumusan TPK mengacu pada teori kecerdasan intrapersonal dan karakteristik kecerdasan intrapersonal.

Langkah kelima, menulis tes acuan patokan dengan menggunakan tabel spesifikasi atau kisi-kisi yang sederhana. Tes yang telah dikembangkan digunakan untuk mengukur tingkat penguasaan mahasiswa dalam setiap bagian pelajaran atau seluruh mata pelajaran. Kegiatan ini merupakan hasil dari dua proses yaitu hasil kegiatan melakukan analisis pembelajaran, serta mengidentifikasi perilaku dan karakteristik awal mahasiswa.

Langkah keenam, menyusun strategi pembelajaran. Di dalam langkah keenam ini terdapat 
konsep strategi pembelajaran sebagai urutan kegiatan pembelajaran yang dikaitkan dengan metode, media yang digunakan, dan waktu yang dibutuhkan pembelajar dan mahasiswa untuk mencapai tujuan pembelajaran tertentu. Strategi pembelajaran yang digambarkan oleh MPI bukan saja cara tentang bagaimana tujuan pembelajaran dicapai, melainkan juga dengan alat apa dan berapa besar usaha yang harus dilaksanakan pembelajar dan mahasiswa. Selain itu, strategi pembelajaran yang akan dikembangkan akan membawa mahasiswa pada suatu proses pembelajaran yang bermakna, menyenangkan, melibatkan mahasiswa secara aktif, dan menstimulus berbagai aktualisasi potensi diri yang dimiliki mahasiswa.

Konsep belajar aktif (active learning) akan direalisasikan dalam pelatihan pengembangan kecerdasan intrapersonal untuk mahasiswa Teknologi Pendidikan FIP-UNJ reguler angkatan 2004. Dengan belajar aktif, mahasiswa memiliki kesempatan untuk bereksplorasi, menemukan, berimajinasi, berefleksi, berkreasi, mengekspresikan pikiran dan perasaannya sendiri, berbagi ide/gagasan dengan mahasiswa lain, dan belajar secara menyenangkan. Selain itu, melalui belajar aktif mahasiswa akan dapat memahami siapa dirinya (kekuatan dan kelemahan diri), mengembangkan konsep diri yang baik, mengembangkan kecerdasan emosional, motivasi, komunikasi intrapersonal, serta strategi belajar yang efektif dan efisien. Perilaku (kompetensi) khusus yang ingin dicapai tersebut berdasarkan pada TPK yang telah di uraikan sebelumnya.

Pemberian stimulus yang tepat mengacu pada tahap perkembangan mahasiswa, yaitu masa remaja akhir. Strategi belajar aktif akan dikemas dalam suasana yang menggairahkan, partisipatif, dan bermakna. Secara langsung maupun tidak langsung, melalui kegiatan belajar aktif mahasiswa akan memperoleh pengetahuan, keterampilan, dan dapat mengembangkan berbagai potensi diri yang dimilikinya.

Langkah ketujuh, mengembangkan bahan pembelajaran berdasarkan strategi pembelajaran dan tes yang telah disusun. Pengembangan bahan pembelajaran yang akan dikembangkan di sini adalah pembelajar sebagai penyaji bahan belajar yang dipilihnya disingkat Pembelajar, Bahan dan Siswa (PBS). Pelatihan pengembangan kecerdasan intrapersonal sebagai hasil dari pengembangan pembelajaran akan mengkombinasikan berbagai metode, memanfaatkan sumber belajar yang variatif, dan mengkondisikan suasana yang menggairahkan.
Langkah kedelapan dalam MPI adalah menyusun desain dan melaksanakan evaluasi formatif. Evaluasi formatif bertujuan untuk menentukan apa yang harus ditingkatkan atau direvisi agar produk tersebut lebih efektif dan lebih efisien, Idealnya, pengembang pembelajaran melakukan empat tahap evaluasi formatif yaitu: (1) dikaji oleh ahli bidang studi di luar tim pengembang pembelajaran, (2) evaluasi satu-satu (one-to-one evaluation), (3) evaluasi kelompok kecil, dan (4) uji coba lapangan. Langkah kesembilan adalah langkah terakhir, yaitu menghasilkan sistem pembelajaran.

Melalui pelatihan pengembangan kecerdasan intrapersonal diharapkan mahasiswa Teknologi Pendidikan FIP-UNJ reguler angkatan 2004 dapat mengatasi masalah krisis identitas, memiliki motivasi yang tinggi dalam belajar, dan mampu mengaktualisasikan potensi diri yang dimilikinya. Dengan memperhatikan rumusan kompetensi yang ingin dicapai secara spesifik, jelas dan terukur (dituangkan dalam TPK); strategi penyampaian yang menekankan keaktifan mahasiswa, penggunaan metode kolaboratif, manajemen waktu yang tepat; serta sistem evaluasi yang tidak hanya mengacu pada daya ingat saja, tetapi lebih kepada kemampuan berpikir logis, kreatif, analitis, dan sistematis yang membantu memecahkan masalah belajar mahasiswa.

\section{METODOLOGI PENELITIAN}

Berdasarkan masalah dan tujuannya, penelitian ini termasuk penelitian deskriptif yang tidak memerlukan perumusan hipotesis. Berdasarkan metodenya, penelitian ini digolongkan sebagai penelitian kualitatif. Jenis penelitian ini bersifat pengembangan (developmental) jika dilihat dari tujuannya, yaitu menghasilkan sebuah paket pelatihan (sistem pembelajaran) yang merupakan salah satu tahap dalam pengembangan pembelajaran. Dilihat dari ruang lingkupnya, penelitian ini termasuk penelitian kasus karena Paket Pelatihan Pengembangan Kecerdasan Intrapersonal ini hanya dapat diberlakukan di Program Studi Teknologi Pendidikan FIP-UNJ yang memiliki visi, misi, dan karakteristik yang berbeda dengan program studi lainnya. Walaupun demikian, tidak tertutup kemungkinan untuk mengembangkan Paket Pelatihan Pengembangan Kecerdasan Intrapersonal ini secara meluas pada tingkat fakultas dan universitas.

Penelitian pengembangan ini menerapkan kesembilan langkah yang terdapat di dalam model MPI. Langkah-langkah di dalam model MPI terdiri atas tiga tahap. Tahap pertama, mengidentifikasi yang 
terdiri atas langkah pertama: mengidentifikasi kebutuhan pembelajaran dan menulis tujuan pembelajaran umum, langkah kedua: melakukan analisis pembelajaran, selanjutnya langkah ketiga: mengidentifikasi perilaku dan karakteristik awal mahasiswa. Selanjutnya tahap kedua, mengembangkan bahan pembelajaran terdiri atas empat langkah yaitu menulis TPU, menulis tes acuan patokan, menyusun strategi pembelajaran, dan mengembangkan bahan pembelajaran. Tahap ketiga, mengevaluasi dan merevisi, yaitu mendesain dan melaksanakan evaluasi formatif yang termasuk di dalamnya kegiatan merevisi produk.

Adapun responden dalam penelitian pengembangan ini adalah mahasiswa Program Studi Teknologi Pendidikan FIP-UNJ reguler angkatan 2004 yang berjumlah 22 orang dari jumlah keseluruhan yaitu 42 orang. Penetapan jumlah responden 22 orang berdasarkan ketentuan yang ada dalam Model MPI pada langkah kedelapan, sebagai berikut.

1. Uji coba small group 7 orang responden: 4 orang perempuan dan 3 orang laki-laki.

2. Uji coba lapangan 15 orang responden: 14 orang perempuan dan 1 orang laki-laki.

3. Sisanya, 20 orang mahasiswa tidak bisa mengikuti pelatihan kecerdasan intrapersonal karena berbagai alasan, seperti: lebih memprioritaskan kegiatan lain pada saat pelatihan dilaksanakan, jarak rumah yang terlalu jauh dari kampus, serta berhalangan hadir karena sakit.

Dalam mengevaluasi pelatihan pengembangan kecerdasan intrapersonal untuk mahasiswa Program Studi Teknologi Pendidikan FIP-UNJ reguler angkatan 2004 digunakan angket terbuka dan skala semantik diferensial, serta konfirmasi kepada nara sumber (ahli desain pembelajaran dan ahli materi) melalui wawancara. Tujuan menggunakan skala penilaian semantik diferensial, angket terbuka, dan wawancara dalam mengevaluasi pelatihan pengembangan kecerdasan intrapersonal adalah untuk mengetahui desain pembelajaran dan kelengkapannya yang telah dikembangkan, serta sebagai bahan pertimbangan untuk melakukan revisi terhadap komponenkomponen dalam pelatihan pengembangan kecerdasan intrapersonal. Informasi-informasi yang diperoleh dari evaluasi terhadap pelatihan, baik pada tingkat ahli, kelompok kecil (small group) dan uji coba lapangan dianalisa dengan metode deskriptif kualitatif. Teknik analisis data yang digunakan, yaitu mengidentifikasi kelebihan dan kekurangan, serta saran perbaikan terhadap pelatihan yang telah dinilai oleh para ahli dan respon mahasiswa.
Uji validitas yang digunakan dalam penelitian ini adalah validitas logis. Dalam hal ini, instrumen yang sudah sesuai dengan isi disebut validitas isi, sedangkan yang sudah sesuai dengan aspek yang diungkap disebut validitas konstruksi. Validitas instrumen yang digunakan dalam penelitian ini divalidasi oleh dosen ahli materi (untuk kisi-kisi instrumen tes pelatihan) dan dosen pembimbing (untuk angket terbuka dan skala semantik diferensial). Sedangkan reliabilitas instrumen, oleh karena uji validitas logis, tidak perlu diperhitungkan reliabilitasnya secara statistik (Nawawi, 1995:177).

\section{Prosedur Pengembangan}

Di samping mengikuti prosedur penerapan MPI, dalam mengembangkan pelatihan kecerdasan intrapersonal untuk mahasiswa Program Studi Teknologi Pendidikan FIP-UNJ reguler 2004 disesuaikan dengan prinsip dan pendekatan psikologis masa remaja akhir yaitu usia 18-21 tahun. Inti dari pengembangan pelatihan kecerdasan intrapersonal adalah mendesain dan mengembangkan pelatihan berdasarkan prinsip-prinsip pendekatan pembelajaran di perguruan tinggi dan pembelajaran belajar aktif (active learning) yang akan memberikan kesempatan kepada mahasiswa untuk bereksplorasi, menemukan, berimajinasi, berefleksi, berkreasi, mengekspresikan pikiran dan perasaannya sendiri, berbagi ide/gagasan dengan mahasiswa lain, dan belajar dengan menyenangkan.

\section{HASIL PENELITIAN}

Setelah melalui serangkaian tahap dalam menerapkan MPI di dalam pelatihan kecerdasan intrapersonal, ditetapkanlah "Paket Pelatihan Pengembangan Kecerdasan Intrapersonal untuk mahasiswa Program Studi Teknologi Pendidikan FIP-UNJ reguler angkatan 2004" sebagai nama produk hasil pengembangan.

Paket Pelatihan Pengembangan Kecerdasan Intrapersonal ini dirancang dan dikembangkan untuk tiga hari kegiatan yang terdiri dari tujuh pokok bahasan yaitu konsep diri dan kecerdasan intrapersonal untuk hari pertama pelatihan, hari kedua pelatihan mencakup pokok bahasan kecerdasan emosional, motivasi internal, dan komunikasi intrapersonal. Hari ketiga mencakup pokok bahasan pengembangan kecerdasan intrapersonal dan strategi belajar efektif dan efisien. Isi Paket Pelatihan Pengembangan Kecerdasan Intrapersonal ini meliputi hal-hal berikut.

1. Rancangan Program: analisis kebutuhan pembelajaran, rumusan TPU, analisis 
pembelajaran, peta kompetensi, rumusan TPK, dan Garis Besar Program Pengajaran (GBPP).

2. Panduan untuk pelatih (trainer): panduan ini membantu trainer dalam penyelenggaraan pelatihan.

3. Kisi-kisi tes dan instrumen tes yang terdiri atas tes awal (pre-test) serta tes akhir (post-test) dilengkapi dengan indikator penilaian tes yang membantu trainer dalam memeriksa hasil tes.

4. Bahan pembelajaran (hand out pelatihan) yang dapat digunakan oleh trainer dan mahasiswa dalam proses pembelajaran; dilengkapi dengan panduan kegiatan untuk mahasiswa dalam mengisi latihan latihan (tes formatif) selama proses pembelajaran berlangsung.

5. Rancangan pelaksanaan pelatihan (jadwal pelatihan).

6. Print out media presentasi power point dan CD presentasi power point.

\section{Karakteristik Produk}

Setelah melalui proses uji coba dan revisi, maka "Paket Pelatihan Pengembangan Kecerdasan Intrapersonal Untuk Mahasiswa Teknologi Pendidikan FIP-UNJ Reguler Angkatan 2004" memiliki karakteristik sebagai berikut.

1. Paket Pelatihan Pengembangan Kecerdasan Intrapersonal dirancang dan dikembangkan untuk tiga hari kegiatan, dengan mengacu pada karakteristik kompetensi lulusan perguruan tinggi, kompetensi lulusan UNJ dan kompetensi lulusan Program Studi Teknologi Pendidikan FIP-UNJ.

2. Paket Pelatihan Pengembangan Kecerdasan Intrapersonal didesain dan dikembangkan menggunakan pendekatan sistem yaitu analisis kebutuhan, perumusan tujuan pembelajaran, analisis pembelajaran, identifikasi karakteristik awal mahasiswa, penyusunan tes acuan patokan, pengembangan strategi pembelajaran, dan bahan pembelajaran, serta evaluasi formatif terhadap desain paket pelatihan pengembangan kecerdasaaan intrapersonal. Tahapan tersebut mengacu pada suatu model yang bernama MPI.

3. Paket Pelatihan Pengembangan Kecerdasan Intrapersonal dirancang berdasarkan analisis kebutuhan dan dikemas dalam bentuk pembelajaran aktif, dengan mengkolaborasikan beberapa metode, serta strategi pembelajaran yang merangsang keaktifan mahasiswa dari berbagai aspek seperti kognitif, afektif, dan psikomotorik.

4. Paket pelatihan ini dirancang dan dikembangkan mengacu pada kompetensi-kompetensi khusus yang akan dicapai mahasiswa setelah mengikuti pelatihan pengembangan kecerdasan intrapersonal ini. Kompetensi-kompetensi khusus tersebut tersusun secara sistematis mulai dari merumuskan konsep diri dengan benar, mengembangkan kecerdasan intrapersonal dengan benar, mengembangkan kecerdasan emosional dengan benar, mengimplementasikan motivasi internal dengan benar, menggunakan komunikasi intrapersonal dengan benar, mengimplementasikan pengembangan kecerdasan intrapersonal dengan benar, serta mengimplementasikan strategi belajar secara efektif dan efisien dengan benar.

5. Sasaran pelatihan pengembangan kecerdasan intrapersonal adalah mahasiswa Teknologi Pendidikan FIP-UNJ reguler angkatan 2004 (usia 19-21 tahun) untuk kelas dengan jumlah siswa 816 orang. Sebaiknya trainer didampingi oleh minimal dua orang yang membantu dalam proses kegiatan pembelajaran sekaligus menjadi evaluator pembelajaran.

6. Paket Pelatihan Pengembangan Kecerdasan Intrapersonal ini dirancang dan dikembangkan berdasarkan karakteristik tugas-tugas perkembangan masa remaja akhir (usia 18-21 tahun).

7. Media pembelajaran yang digunakan dalam Paket Pelatihan Pengembangan Kecerdasan Intrapersonal ini berupa media film yang digunakan pada pokok bahasan konsep diri, media presentasi power point yang digunakan pada setiap pokok bahasan, serta musik instrumental yang selalu mengiringi proses pembelajaran sehingga membuat proses pembelajaran menjadi lebih nyaman dan menggairahkan.

8. Metode pembelajaran yang digunakan sangat variatif selain ceramah, kerja kelompok, dan diskusi, dilengkapi juga dengan metode studi kasus, refleksi diri, games, meditasi, menulis buku harian, menulis jurnal belajar dan sebagainya.

9. Bahan pembelajaran yang dikembangkan dalam paket pelatihan ini berupa hand out pelatihan yang digunakan dalam proses pembelajaran berlangsung. Hand out dirancang dan dikem-bangkan secara sistematis berdasarkan ketujuh pokok bahasan yang telah dirumuskan sebelumnya. Hand out pelatihan berisi uraian materi setiap pokok bahasan beserta contoh-contohnya dan latihanlatihan (tes formatif) dilengkapi dengan panduan/ prosedur kegiatan yang dilakukan mahasiswa selama proses pembelajaran berlangsung.

10. Paket Pelatihan Pengembangan Kecerdasan Intrapersonal berisi panduan untuk trainer yang 
akan membantu trainer dalam penyelenggaraan pelatihan. Panduan untuk trainer ini berisi narasi kegiatan pelatihan selama tiga hari, dan strategi pembelajaran yang akan diterapkan; serta kisi-kisi tes, instrumen tes dan indikator penilaian tes yang akan membantu trainer dalam menyelenggarakan tes dan memeriksa hasil tes mahasiswa.

11. Dalam melaksanakan uji coba Paket Pelatihan Pengembangan Kecerdasan Intrapersonal selalu dilakukan evaluasi, baik itu sebelum memulai pembelajaran, pada proses pembelajaran, maupun hasil akhir dari pembelajaran dalam bentuk pretest, tes formatif, dan post-test. Pada intinya, Paket Pelatihan Pengembangan Kecerdasan Intrapersonal tidak hanya menilai pencapaian mahasiswa di akhir pembelajaran, tetapi juga memperhatikan proses mereka ketika berpartisipasi dalam kegiatan pembelajaran. Paket Pelatihan Pengembangan Kecerdasan Intrapersonal menekankan pada partisipasi siswa dalam mengikuti proses pembelajaran dan ketercapaian kompetensi oleh siswa, baik secara individu maupun kelompok.

\section{Prosedur Pemanfaatan}

Paket Pelatihan Pengembangan Kecerdasan Intrapersonal untuk mahasiswa Teknologi Pendidikan FIP-UNJ reguler angkatan 2004 dengan jumlah peserta 8-16 orang. Alasan pemanfaatan Paket Pelatihan Pengembangan Kecerdasan Intrapersonal ini selain sebagai solusi permasalahan krisis identitas diri dan kemandekan aktualisasi potensi diri juga mengacu pada kompetensi-kompetensi lulusan perguruan tinggi dan lulusan UNJ serta kompetensi-kompetensi lulusan Program Studi Teknologi Pendidikan FIP-UNJ. Sehingga Paket Pelatihan Pengembangan Kecerdasan Intrapersonal ini sangat relevan dengan kebutuhan mahasiswa Teknologi Pendidikan FIP-UNJ reguler angkatan 2004 yang sedang dalam tahap perkembangan remaja akhir.

Berikut ini adalah tahapan-tahapan dalam memanfaatkan Paket Pelatihan Pengembangan Kecerdasan Intrapersonal untuk mahasiswa Teknologi Pendidikan FIP-UNJ angkatan 2004 sebagai berikut.

1. Pelatih (trainer) memahami rancangan program dan panduan untuk trainer sehingga dapat memahami apa, untuk apa, dan bagaimana Paket Pelatihan Pengembangan Kecerdasan Intrapersonal dilaksanakan.

2. Trainer menguasai bahan pembelajaran (hand out pelatihan) yang akan disajikan kepada mahasiswa sehingga tujuan pembelajaran yang telah ditetapkan dapat tercapai.
3. Trainer memahami kisi-kisi tes, instrumen tes, serta indikator penilaian tes sehingga memudahkan dalam pelaksanaan tes dan memeriksa hasil tes mahasiswa.

4. Trainer berlatih menggunakan media presentasi power point dengan baik sehingga dapat menyajikan presentasi setiap pokok bahasan dengan optimal.

5. Analisis tentang fasilitas yang dibutuhkan maupun fasilitas yang sudah tersedia atau belum tersedia, seperti ruang pelatihan, kelengkapan kursi untuk peserta, white board, LCD projector, laptop/ $\mathrm{PC}$, dan pendingin ruangan (AC).

6. Mempersiapkan pelatihan.

a) Baca petunjuk kegiatan/prosedur pemanfaatan Paket Pelatihan Pengembangan Kecerdasan Intrapersonal (panduan untuk trainer).

b) Persiapkan setting (lingkungan belajar dan mahasiswa) dan perlengkapan pembelajaran lainnya, sesuai dengan petunjuk kegiatan dalam panduan untuk trainer.

7. Implementasikan pelatihan pengembangan kecerdasan intrapersonal berdasarkan deskripsi yang dituangkan di dalam panduan untuk trainer.

8. Evaluasi pelatihan pengembangan kecerdasan intrapersonal dengan menggunakan instrumen tes baik tes awal (pre-test) dan tes akhir (post-test). Periksa hasil tes berdasarkan indikator penilaian yang telah dirumuskan.

\section{KESIMPULAN}

\section{Kesimpulan}

Penerapan MPI di dalam menyusun paket pelatihan kecerdasan intrapersonal telah menghasilkan produk Paket Pelatihan Kecerdasan Intrapersonal untuk Mahasiswa Program Studi Teknologi Pendidikan FIP-UNJ Reguler Angkatan 2004. Paket pelatihan tersebut mengacu pada kompetensi lulusan perguruan tinggi, kompetensi lulusan UNJ, dan kompetensi lulusan jurusan Kurikulum dan Teknologi Pendidikan, dan sejak awal perencanaannya memiliki rumusan tujuan pembelajaran yang ingin dicapai secara spesifik, jelas dan terukur; strategi penyampaian yang menekankan keaktifan mahasiswa, dengan menggunakan metode kolaboratif dan manajemen waktu yang tepat; serta sistem evaluasi yang tidak hanya mengukur daya ingat saja, tetapi lebih kepada kemampuan berpikir logis, kreatif, analitis, dan sistematis.

Paket Pelatihan Pengembangan Kecerdasan Intrapersonal untuk mahasiswa Program Studi Teknologi Pendidikan FIP-UNJ reguler angkatan 2004 meliputi sebagai berikut. 
1. Rancangan program: analisis kebutuhan pembelajaran, rumusan TPU, analisis pembelajaran, peta kompetensi, rumusan TPK, dan Garis Besar Program Pengajaran (GBPP).,

2. Panduan untuk pelatih (trainer); panduan ini membantu trainer dalam penyelenggaraan pelatihan.

3. Kisi-kisi tes dan instrumen tes yang terdiri dari tes awal (pre-test) dan tes akhir (post-test); dilengkapi dengan indikator penilaian tes yang membantu trainer dalam memeriksa hasil tes.

4. Bahan pembelajaran (hand out pelatihan) yang dapat digunakan oleh trainer dan mahasiswa dalam proses pembelajaran; dilengkapi dengan panduan kegiatan untuk mahasiswa dalam mengisi latihanlatihan (tes formatif) selama proses pembelajaran berlangsung.

5. Rancangan pelaksanaan pelatihan (jadwal pelatihan).

6. Print out media presentasi power point dan CD presentasi power point.

Berdasarkan hasil uji coba kelompok kecil (small group) dan uji coba lapangan (field trial), maka dapat disimpulkan bahwa Paket Pelatihan Pengembangan Kecerdasan Intrapersonal layak dilaksanakan di Program Studi Teknologi Pendidikan FIP-UNJ, dan dinilai kreatif, inovatif, efektif, dan efisien.

\section{Implikasi}

Paket Pelatihan Pengembangan Kecerdasan Intrapersonal tidak hanya berimplikasi pada mahasiswa Program Studi Teknologi Pendidikan FIPUNJ reguler angkatan 2004 tetapi juga berimplikasi pada trainer sebagai faslitator pelatihan yang akan menggunakan paket pelatihan ini, dan Program Studi Teknologi Pendidikan FIP-UNJ sebagai salah satu lembaga yang bertujuan menghasilkan tenaga ahli dalam bidang teknologi pendidikan, salah satunya ahli dalam mengelola sistem pembelajaran/pelatihan.

A. Bagi mahasiswa program studi teknologi pendidikan FIP-UNJ reguler angkatan 2004

Implikasi Paket Pelatihan Pengembangan Kecerdasan Intrapersonal bagi mahasiswa Program Studi Teknologi Pendidikan FIP-UNJ reguler angkatan 2004 sebagai subjek belajar adalah bahwa mereka memiliki hak dan kesempatan untuk mengetahui dan memahami identitas dirinya, mengembangkan potensi-potensi yang ada di dalam dirinya serta mengaktualisasikan potensi dirinya di kehidupan sehari-hari melalui serangkaian aktivitas positif yang aktif, interaktif, menggairahkan, dan bermakna. Tuntutan akan pengelolaan dan pelaksanaan kegiatan pembelajaran yang bermakna dan menggairahkan dalam rangka merangsang berbagai potensi diri yang dimiliki mahasiswa, baik secara individu maupun kelompok, dengan rumusan kompetensi yang jelas, penggunaan strategi dan metode yang variatif dan kolaboratif, serta evaluasi yang tidak hanya mengukur daya ingat, tetapi kemampuan berpikir logis, kreatif, analitis dan sistematis, merupakan karakteristik dari Paket Pelatihan Pengembangan Kecerdasan Intrapersonal untuk mahasiswa Program Studi Teknologi Pendidikan FIP-UNJ reguler angkatan 2004. Kebermaknaan yang dimaksud adalah mahasiswa mengetahui dan memahami bahwa setiap pengetahuan dan potensi diri yang dimilikinya dapat diaktualisasikan dan bermanfaat bagi kehidupan sehari-hari.

\section{B. Pelatih (trainer)}

Implikasi Paket Pelatihan Pengembangan Kecerdasan Intrapersonal untuk mahasiswa Teknologi Pendidikan FIP-UNJ reguler angkatan 2004 bagi pelatih (trainer) sebagai fasilitator pelatihan adalah tuntutan untuk memiliki pengetahuan, pemahaman, dan keterampilan dalam mata pelatihan kecerdasan intrapersonal. Kemampuan mensinergikan setiap pokok bahasan yang ada di dalam pelatihan kecerdasan intrapersonal sehingga mencapai tujuan pembelajaran yang telah ditetapkan sebelumnya.

Trainer memiliki peran yang penting dalam mengimplementasikan Paket Pelatihan Pengembangan Kecerdasan Intrapersonal. Trainer sebagai fasilitator pembelajaran bertanggung jawab dalam menyajikan materi pelatihan, membimbing dan mengarahkan mahasiswa dalam proses pembelajaran, serta mengevaluasi proses pembelajaran tersebut. Sebaiknya trainer juga memiliki kemampuan berkomunikasi dengan baik, mampu menjalin hubungan emosional dan menjalin keakraban dengan mahasiswa sehingga menciptakan lingkungan belajar yang kondusif. Selain itu, trainer juga harus dapat menginspirasi, memotivasi mahasiswa selama proses pembelajaran, serta melibatkan mahasiswa secara aktif dalam proses pembelajaran. Selain itu, seorang trainer harus mampu mengelola waktu pelatihan dengan tepat, terampil dalam memanfaatkan metode dan media pembelajaran, serta sumber belajar yang tersedia.

C. Bagi program studi teknologi pendidikan FIP-UNJ Beberapa prinsip pelatihan pengembangan kecerdasan intrapersonal mengacu pada kompetensi lulusan Program Studi Teknologi Pendidikan FIP-UNJ yaitu kompetensi pengembangan kepribadian dan keprofesionalan. Kompetensi-kompetensi tersebut adalah mampu: (a) menilai kinerja sendiri yang 
merupakan kemampuan merefleksikan diri, (b) bekerja mandiri merupakan kemampuan untuk bekerja secara mandiri, (c) mencari dan memanfaatkan sumber informasi yang relevan merupakan kemampuan untuk mengembangkan kemampuan belajar yang berkelanjutan dan meningkatkan diri, serta (d) memiliki komitmen terhadap profesi dan tugas profesional merupakan kemampuan dalam mengembangkan konsep diri yang baik.

Program Studi Teknologi Pendidikan FIP-UNJ merupakan salah satu lembaga penyelenggara pendidikan di perguruan tinggi yang bertujuan menghasilkan tenaga ahli dalam bidang Teknologi Pendidikan yang memiliki keahlian khusus. Salah satu keahlian khusus tersebut adalah pengelola sistem pembelajaran. Pengembangan Paket Pelatihan Kecerdasan Intrapersonal untuk mahasiswa Program Studi Teknologi Pendidikan FIP-UNJ reguler angkatan 2004 merupakan salah satu bentuk keahlian khusus dalam merencanakan dan mengembangkan suatu paket pembelajaran (pelatihan) yang merupakan bagian sistem pembelajaran. Kompetensi yang akan dikuasai oleh para lulusan Teknologi Pendidikan adalah mampu merancang, mengembangkan, memanfaatkan, mengelola, dan mengevaluasi proses pembelajaran maupun berbagai sumber belajar secara efektif dan efisien.

Saran

Beberapa saran sehubungan dengan proses mengembangkan dan mengimplementasikan Paket Pelatihan Pengembangan Kecerdasan Intrapersonal untuk Mahasiswa Program Studi Teknologi Pendidikan FIP-UNJ Reguler Angkatan 2004 adalah sebagai berikut.

1. Untuk Mahasiswa Program Studi Teknologi Pendidikan FIP-UNJ reguler angkatan 2004: agar terus berusaha mengembangkan kecerdasan intrapersonal dengan mengimplementasikan pengetahuan dan keterampilan yang diperoleh dari pelatihan pengembangan kecerdasan intrapersonal di dalam kehidupan sehari-hari.

2. Untuk Mahasiswa Program Studi Teknologi Pendidikan FIP-UNJ: agar membuat kajian pengembangan pembelajaran yang lebih kreatif dan inovatif serta bermanfaat untuk orang banyak dan Program Studi Teknologi Pendidikan FIP-UNJ.

3. Untuk Program Studi Teknologi Pendidikan FIPUNJ:

a) agar mendukung pelaksanaan pelatihan pengembangan kecerdasan intrapersonal selanjutnya untuk semua mahasiwa Program Studi Teknologi Pendidikan FIP-UNJ angkatan 2004, dan

b) agar mendorong mahasiswa Program Studi Teknologi Pendidikan FIP-UNJ untuk terus berkarya dengan memberikan rangsangan kajian/seminar/pelatihan yang berkaitan dengan pengembangan diri.

4. Untuk FIP-UNJ:

a) agar mendukung pengembangan paket pelatihan kecerdasan intrapersonal sehingga dapat disesuaikan dengan kebutuhan mahasiswa program studi di FIP-UNJ, dan

b) agar mendukung pelaksanaan pelatihan pengembangan kecerdasan intrapersonal untuk semua mahasiswa FIP-UNJ.

\section{DAFTAR PUSTAKA}

Arikunto, S. (2003). Manajemen penelitian. Jakarta: PT Rineka Cipta.

Armstrong, T. (2004). Menerapkan $m$ ultiple intelligences di sekolah. Bandung: Penerbit kaifa.

Nawawi, H. (1995). Instrumen penelitian bidang sosial. Jakarta: Gajah Mada University Press.

Suparman, A. M. (2001). Desain instruksional. Jakarta: PAU-PPAI Universitas Terbuka.

Universitas Negeri Jakarta. (2005). Buku pedoman akademik. Jakarta: Universitas Negeri Jakarta.

\section{KETERANGAN PENULIS}

Rina Sukawati, S.Pd., dilahirkan di Jakarta, Januari 1985. Saat ini penulis aktif sebagai Asisten Dosen Teknologi Pendidikan, Staf Jurnal FIP UNJ. Selain itu, sebagai trainer di Solusi Masalah Kawula Muda Instructional and Training Center. 